\title{
الصلابة النفسية عند الأطفال
}

\author{
أعراد \\ الباحث/ وليد عبد الرحمن محمد شاغوش
}

إشر افــ

أ ـ د/ حسيز محمد سعد الدين الحسيني

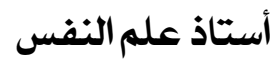

بكليتت الآداب - جامعتما المنصورة

المجلت العلميتّ لكليت رياض الأطفال ـ جامعت المنصورة

المجلد الخامس ـ العدد الأول

يوليو ب.1A 


\section{الصلابة النفسية عند الأطفال}

أر وليد عبد الرحمن محمد شاغوش * - ( )

ثرى كوباز ا ان مفهوم الصلابة النفسية مكون من ثلاثة مفاهيم أو مكونات

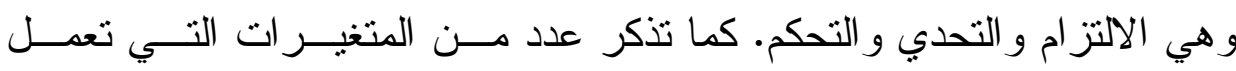

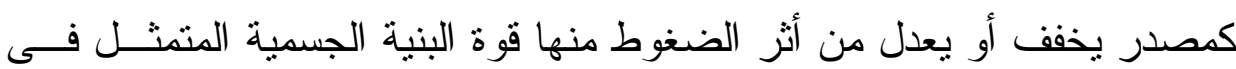
جهاز المناعة ذي الاداء الوظيفي الجيد، وتاريخ العائلة الــصدي الخــالي مــن

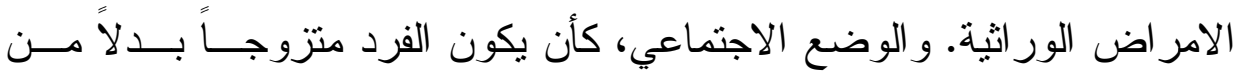

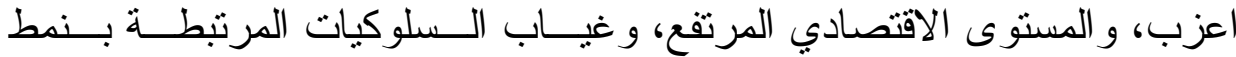

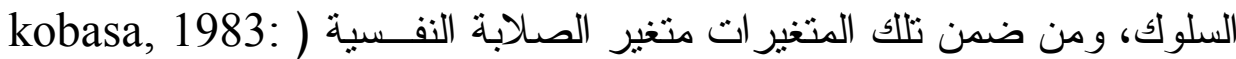

ويختلف الافراد فى كفاءتهم فى مواجهة الضغوط أو التو افق معها. وقــــ

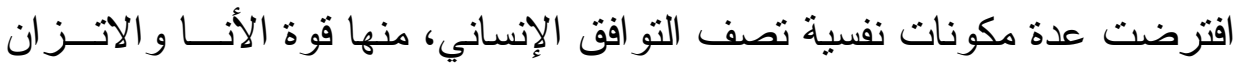

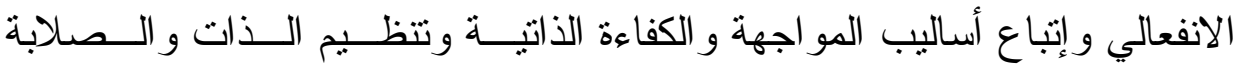
النفسية. وقد بدأ الباحثون فى تحديد السمات الثخصية للأفـــر اد، الــذين يتبعــون

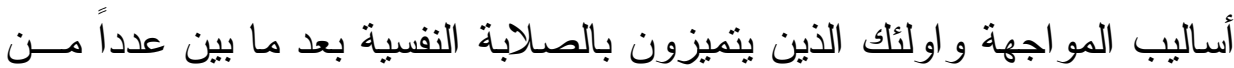
البحوث التي اجر اها (Dohrenwend, 1974) ان الــضغوط النفـسية تـــنبط

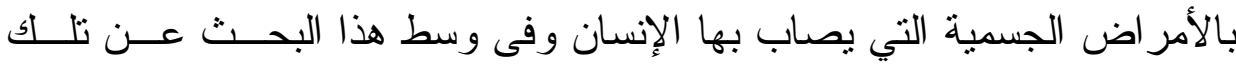
"باحث * 
العو امل المساعدة على تقليل ومقاومة أثر الضغوط قدمت كوباز ا مفهوم الصلابة النفسية وحسب النظرية التي صاغتها كوباز ا، ترى ان الـصلابة صــفه عامــة تظهر من معايشة خبر ات فى مرحلة الطفولة معززة مثيرة متتوعة وتظهر هـــهـ الصفة من خلال المشاعر و السلوكيات التي تتصف بالالتز ام و التحكم و التحسدي

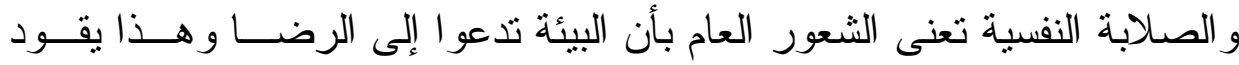
الفرد إلى ان ينظر إلى المو اقف المتعددة بنوع من الفضول و الحماسة أو الالتز ام

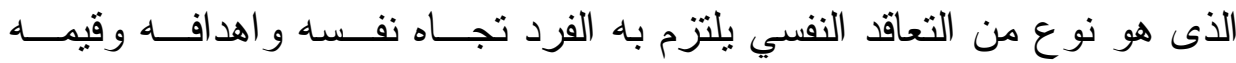
و الاخرين من حوله وينظر إلى المو اقف الضاغطة إن ور ائها معنى و إنها شـى لهى

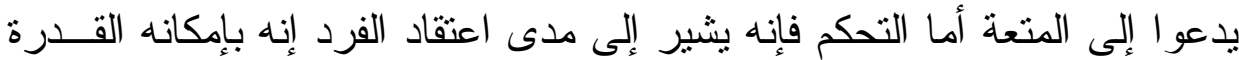
على التحكم فيما يلقاه من احداث، ويتحمل المسؤولية الثخصية عما يحدث لــهـ. (Low, J. ,2006: 36)

و هذا يؤكد ان الضغوط ليست امور اً ثابتة ولكنها متغيــره. أمــــا التحـدي فهو اعتقاد للفرد ان ما يطر أ على جو انب حياتــهـ مــن تغييــر أو امــر مثنـــر

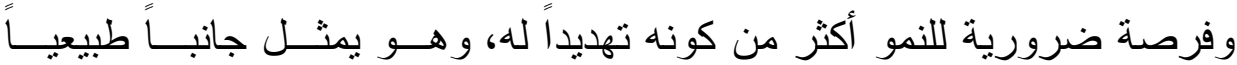

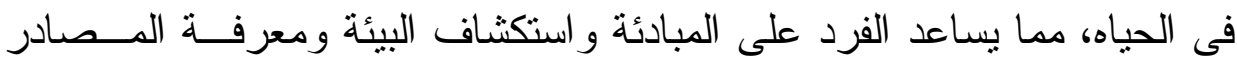
النفسية و الاجتماعية التي تساعد الفرد على مو اجهة الــضنغوط بكفـــاءة ويعــول

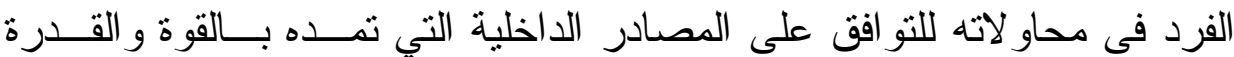

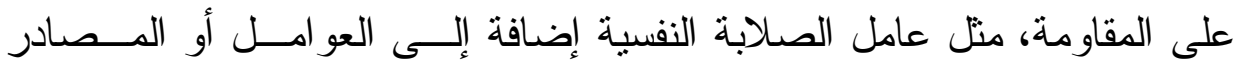

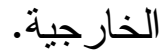

وفى هذا الصدد تذكر كوباز ا دراسة انتونوفسكى الذى قدم فيها نموذجــاً

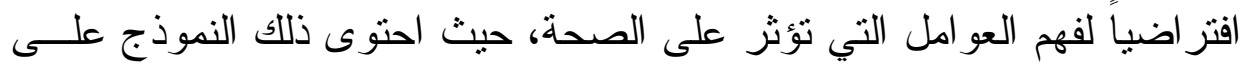


ثمانية انواع من المصادر العامة للمقاومة، وهــي الحالـــة الجـسمية و الحالــهـ البيولوجية، وتوفر الأدوات الحديثة و النو احي المعرفيــة و النــــواحي الانفعاليـــة و الاتجاهات و القيم و العلاقات الثخصية و الجو انــب الاجتماعبــة و الثخــصـية، وتعمل كل تلاك العو امل متضمنـه المساعدة فى التعامل مع التــوتز النــاتج عـنـ الضغوط كما أثنار انتونوفكسى نقلاًعن كوباز ا وبوستى.

وكما تزى كوباز ا فان الصلابة النفسية تعمل على تسهيل أنواع العمليــات فـى الإدر الك و التقويم و المو اجهة التي يقوم بها الفرد وبالتالي تقوده نحـــو الحــل الناجح للموقف الناتج عن الاحداث الضاغطة.) Kobasa, 1983 (

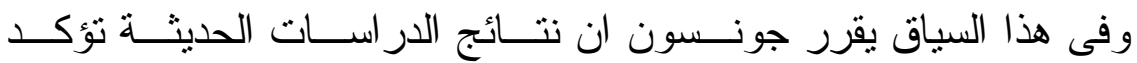
أن ادر الك الفرد بأن لديه مقاومة وصلابة نفسية بــساعد علـى التتبــؤ بمــدى إستمتاعة بالسعادة مستقبلاً وينظر إلى الصلابة النفسية أو المقاومة علــى انهــا

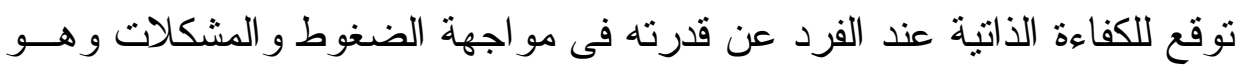
يستعين بمفهوم الكفاءة الذاتية الذى افترضه باندور ا ج1919 و الذى يقـرر بـأن

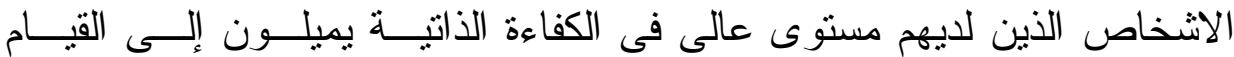
بسلوكيات تقود إلى نتائج ناجحة مع الاعتقــاد بقــدرتهم علــى القيــام بــذلكـ. (Johnson, R.,2004).

و إعتماداً على ذلك المنطق فى التحليل قدمت كوبــاز ا مفهــوم الــصلابة النفسية، حيث إنها نرى ان الفرد الذى يتمتع بالصلابة اقل احتمالاً للإصابة مــن

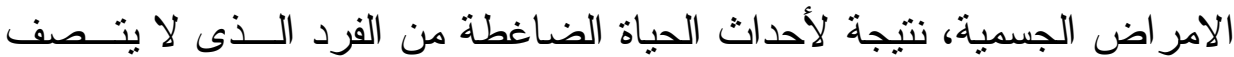
بقدر عالي من الصلابة النفسية. 
وقد اعتمدت كوباز ا فى صياغتها لذلك الدفهوم على نتائج بحوثهــا التــي اجرتها على مديرين العمل التتفيذين فى البرنامج المعروف بمـشروع شــــاغو للضغوط. وفى ذلك المشروع حددت كوباز ا المديرين التنفيذين فى المـستوويين العالي و المتوسط، و الذين بحكم طبيعة عملهم وحياتهم يو اجهون قدر ا عالياً مسن

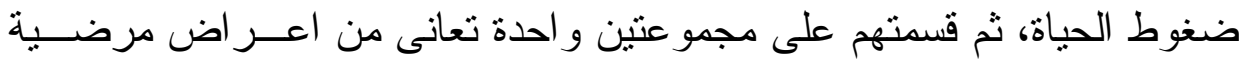

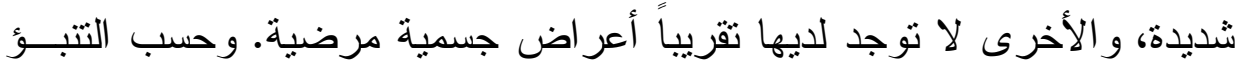

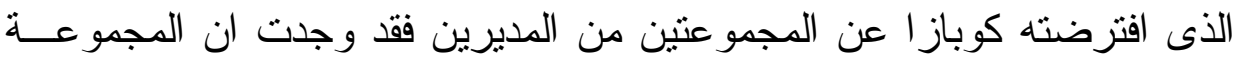

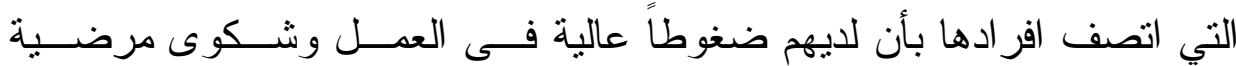
منخفضة، اظهر أولئك الافر اد صلابة في الثخصية ذات دلالة عاليــة، مقارنـــة بالمجموعة التي لدى افر ادها ضغوط فى العمل ولكن لــديها شـكوى مرضـــية

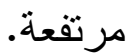

ولم تجد كوباز ا فروق فردية فى الصلابة النفسية تعود إلى بعض العو امل الديموغر افية متل السن و المستوى الوظيفي وفى الدراسات التالية التي اجرتهــا كوباز ا وأخرين وجدت النتيجة نفسها، حيث كان مستوى الصلابة النفسية لــدى لــي

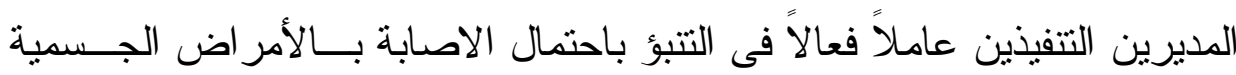
.(kobasa, 1983: 101)

وقد قدمت عدة تفسيرات توضح السبب الذى يجعـل الــصلابة النفـسية تخفف من حدة الضغوط التي نو اجه الفرد. ويمكن فهم تلكك العلاقة مسن خــلد فحص أثز الضغوط على الفرد. وفى هذا الخصوص ترى كل من مادى وكوباز

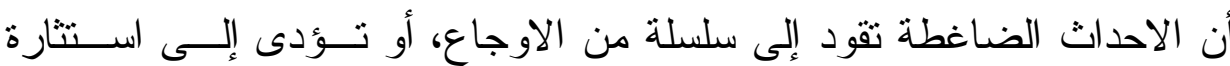

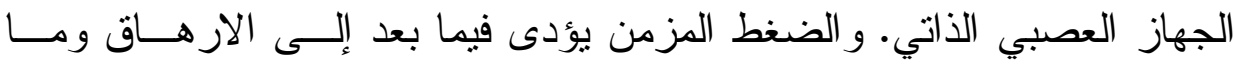


يصاحبه من امر اض جسدية و اضطر ابات نفسية. وهنـــا بــأتى دور الــصلابة النفسية فى تعديل العملية الدائرية، و التي تبدأ بالضغط وتتتهي بالإزهــاق، ويــتـ ذللك من خلال طرق متعددة.

أولاً: الصلابة تعدل من إدر الك الاحداث وتجعلها تبدو اقل وطأة. ثانياً: تؤدى إلى اساليب مو اجهة نشطة أو تتقله من حال إلى حال.

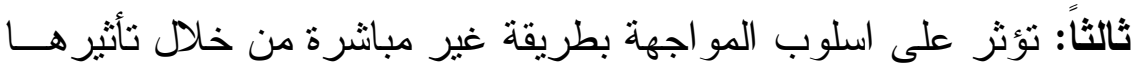

$$
\text { على الدعم الاجتماعي. }
$$

رابعاً: و أخير اً تقود إلىى التغير فى الممارسات الصحية، منل إتباع نظـــام

غذائي صحى، وممارسة الرياضة، و هذه بالطبع تقلل من الإصـــابة

بالأمر اض الجسمية وقد أكدت بحوث أخرى أهمية إدر الك الأحداث

فى الشعور بالضغوط من عدمه..Kelly, 1999: 94)

فالأفر اد ذو و الصلابة النفسية العالية نظريــاً يميلــون إلــى اســتخدام

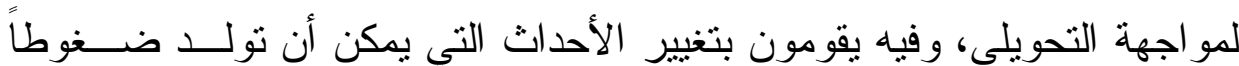
إلى فرص للنمو، ونتيجة لذلك نجدهم يتو افقون مع الأحداث الضاغطة بطريقــة متفائلة وفعالة. و على العكس من ذللك، يعمــد الافــر اد ذوو الــصلابة النفـسية

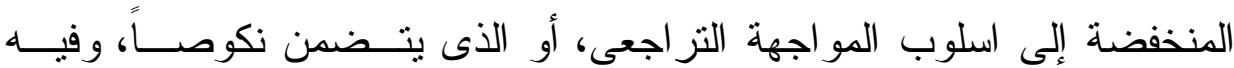

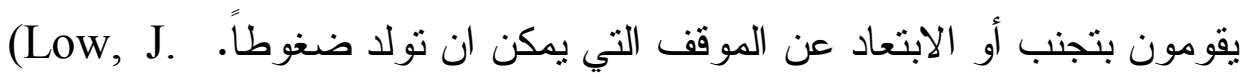
,2006: 39)

و على الرغم من أن الثخص الذى يلجأ لأسلوب النكوص قد يتجنب مؤقتاً المو اقف الضاغطة، فإنه على نحو تشاؤمى يظل مشغولاً بتلك الضغوط مهموماً 
بها. ان استخدام أسلوب المواجهة التز اجعى مرتبط بالزيادة فى مستوى الإحتر اق النفسي بين مدرسى المرحلة الثانوية. وقد ورد عن أولئك المدرســين أن لــديهر مستوى منخفض من الصلابة.

وفيما يلى وصف للأفز اد الذين يمتازون بالصلابة النفسية :

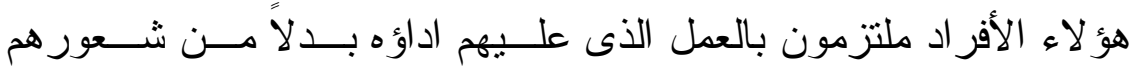
بالغربة. ويشعرون بصفة عامة أن لديهم قدرة على التحكم فى الأحداث، بدلاً من شعور هم بفقدان القوة وينظرون إلى التغيير على انه تحد عــادى بــدلاً مــن ان يشعر هم بالتهديد، وفى إدر اكهم وتقويمهم لأحداث الحياة الضاغطة يحد هــؤلاء (Johnson, R.,2004: 94). الافر اد الفرصة لممارسة إتخاذ القرار أهمية الصلابة النفسية:

قدمت كوباز ا (Kobaza, 1979) عدة تفسير ات توضـــح الـسبب الــذي يجعل الصـابة النفسية تخفف من حدة الضغوط التي تو اجه الفرد، ويمكـن فهــ العلاقة من خلال فحص أثز الضغوط على الفرد، وفي هذا الخصوص نزى كل من بادي كوباز ا أن الأحداث الضاغطة تقود إلى سلسلة من الإرجاع تؤدي إلـى استثارة الجهاز العصبي الذاتي و الضغط المزمن يؤدي فيما بعد إلى الإرهاق وما

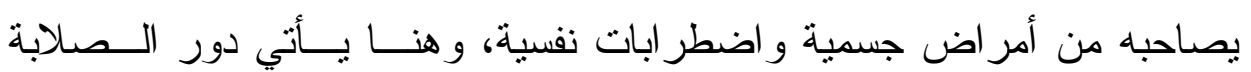
النفسية في تعديل العملية الدائرية، و التي تبدأ بالضغط وتتتهي بالإزهاق. (لولـــوة

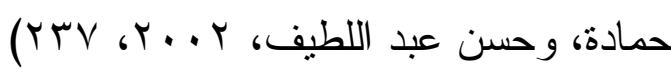
وذكرت شيلي وتايلور (Shely \& Yailor) أنه منذ الدر اسة الأولى التي قامت بها كوباز ا (Kobaza, 1979) أجريت العديد من الأبحاث التي أظهـرت 
أن الصلابة ترتبط بكل من الصحة الجسمية و الصحة النفسية الجيــدة. (ثـــاهر

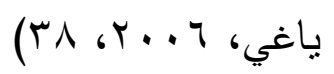

وقد أثـــارت كوبــاز ا (Kobaza, 1979) إلــى أن الــصلابة النفـسية

ومكوناتها تعمل كمتغير سيكولوجي، يخفف من وقع الأحداث الــضاغطة علــى الصحة الجسمية و النفسية للفرد، فالأشخاص الأكثر صلابة يتعرضون للــضغوط الـون و لا يمرضون. (عماد مخيمر، 997 ( 99 (

وقد وجد كل من مادي وكوبــاز ا (Made \& Kobaza) أن الأثــخاص ذوي الصلابة النفسية المرتفعة يكونون أكثز قدرة على الاستفادة مــن أســاليب مو اجهتهم للضغوط بحيث تفيدهم في خفض تهديد الأحداث الضـاغطة من خــله رؤيتها من منظور واسع وتحليلها إلى مركباتها الجزئية ووضع الحلول المناسبة

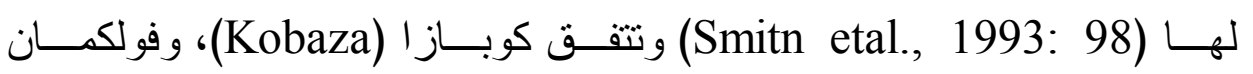
(Volcman)، و لاز اروس (Lazours) في أن الخصائص النفسية كالــصلابة مثنا تؤثر في تقييم الفرد المعرفي للحدث الضـاغط ذاته وما ينطوي عليــه مــن تهديد لأمنه وصحته النفسية وتقديره لذاته، كما تؤثز أيــضـا فــي تقيــيم الفــرد لأساليب المو اجهة وهي الأساليب التي يو اجه بها الفرد الحدث الضاغط (مواجهة المشكلات، الهروب، تحمل المسئولية، البحث عن المـسـاندة، الـتـحكم الــذاتي). ( V^ ، (عماد مخيمر، 997$)$

ويرى باحثون آخرون أنه حتى لو قام الأفر اد الذين يتمتعون بدرجة عالية

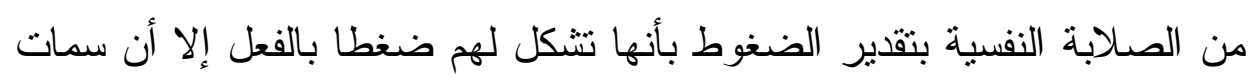
شخصيتهم تظل تعمل كواق من تأثنر الضغوط عن طريق تسهيل اختبار أساليب 


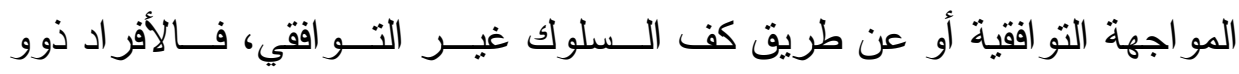

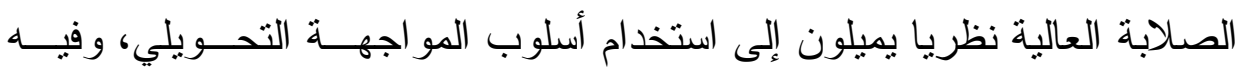

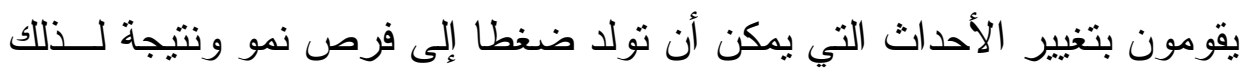
نجدهم يتو افقون مع الأحداث الضاغطة بطريقة متفائلة وفعالة.

و على العكس من ذلك يعتمد الأفر اد ذوو الصلابة المنخفضة إلى أسـلوب إنهاب

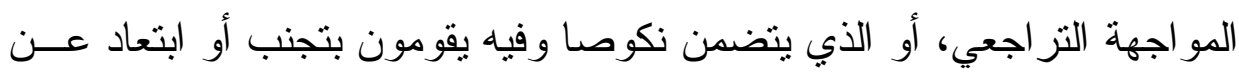

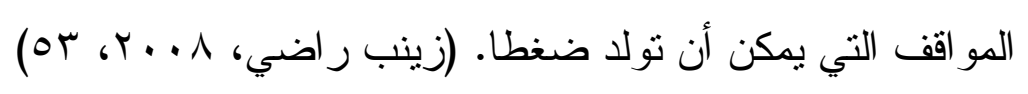

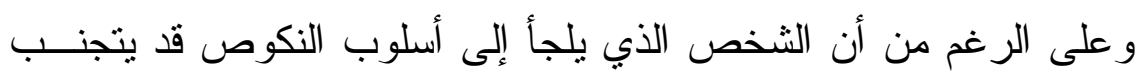

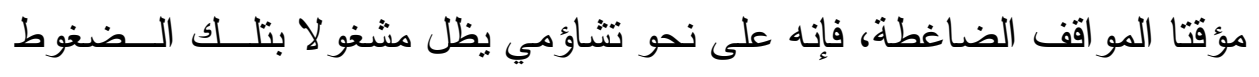
مهوما بها، وقد وجد بيرس ومولي (Peres \& Molly) أن استخدام المو اجهة

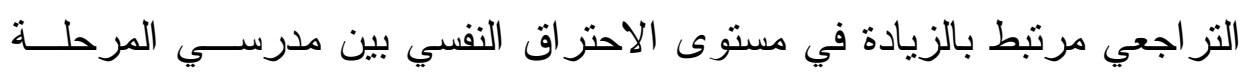

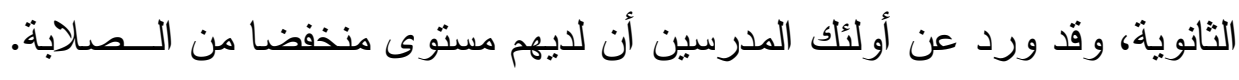

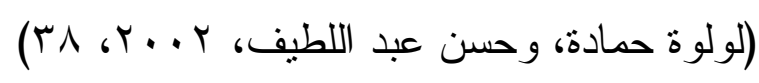

ووجد باجانا (Pagana) نفس النتائج حيث كانت در استه على طلاب كلية

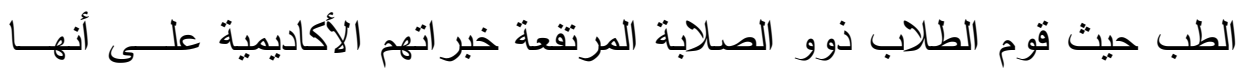
تتثير لديهم التحدي أكثر من أنها تشكل لهم تهديدا، على النقيض من زملائهم ذوو

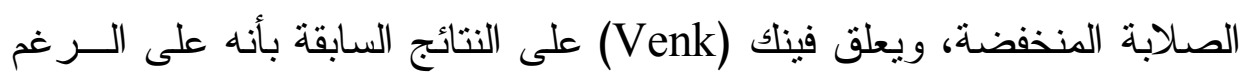

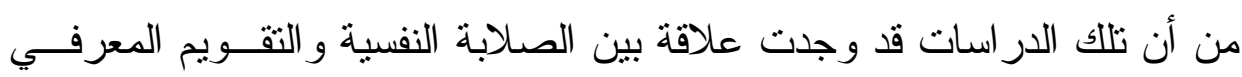

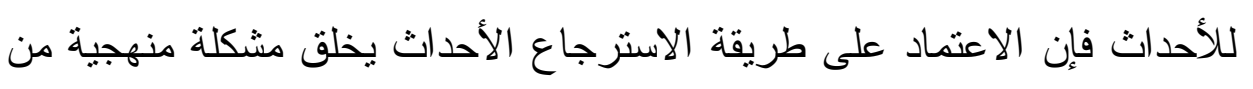

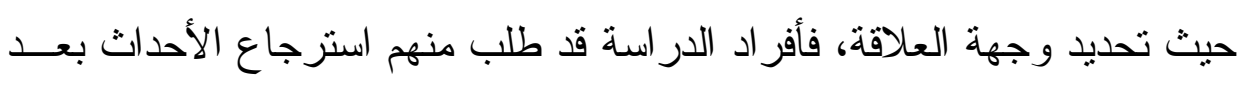


حدوثها ومعايشتهم لها وفي هذه الحالة يصعب تحديد مـــا إذا كانــت الــصلابة النفسية لدى الأفر اد قد عدلت من إدر اكهم للأحداث أو أن الضغوط الناتجة عــن الأحداث نفسها جعلت الأفر اد يكونون أقل صلابة.

وقد لجأت در استان إلى استخدام الضغوط التي تم استحداثها بالتجربة عند أفر اد الدراسة للحد من مشكلة الاسترجاع وجاءت النتائج لتؤكد أيضـا علــى أن الأشخاص الذين لديهم درجة عالية من الصلابة كان تقويمهم للــضغوط أكثــر إيجابية عندما تعرضو المو اقف تهديد. (زينب ر اضي، 1 . . r، سم) إن الصلابة النفسية مركب مهم من مركبات الثخصية القاعدية، التي ثقي الإنسان من آثار الضو اغط الحياتية المختلفة، وتجعل الفرد أكثر مرونة وتفــاؤلا وقابلية للتغلب على مشاكله الضاغطة، كما وتعمل الصلابة النفسية كعامل حماية من الأمر اض الجسدية و الاضطر ابات النفسية. ذكرت شيلي تايلور أنه منذ الدر اسة الأولى التي قامــــ بهـــا (كوبـــاز ا، 9 9 9 أجريت العديد من الأبحـاث (1989-1981) (Kibassz, et al, 1981) التـي أظهرت أن الصلابة النفسية تزتبط بكل من الصحة الجسمية الجيــدة والــصحة

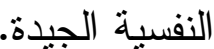

\section{أبعاد الصلابة النفسية:}

توصلت كوباز ا (Kobaza, 1979) إلى ثلاثة أبعاد تتكون فيها الــصلابة

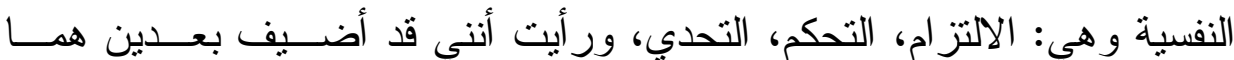
الصبر ، و الإيمان بالقضاء و القدر، وذللك لمناسبتهما للبيئة الفلسطينية التي تتميـز باعتتاق الدين الإسـاهي، وسأتكلم عن هذه الأبعاد بشيء من التفصيل كما يلي: 
أولا: الالتزام:يعتبر مكون الالتز ام من أكثر مكونات الصلابة النفسية ارتباطـــــا بالدور الوقائي للصلابة وصفها مصدر الدقاومة ميز ان المشقة.

تعريف الالتزام: هو اعتقاد الفرد في حقيقة وأهمية وقيمة ذاته، ويمكـن

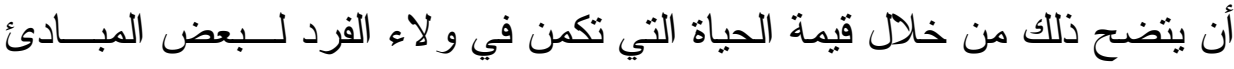
و القيم، و اعتقاده أن لحياته هدفا ومعنى يعيش من أجله. (فاروق السيد عثــــان، $(r), r \ldots)$

ويعرف (عماد مخيمر، لو99 1) أنه نوع من التعاقد النفسي يلتزم به الفرد تجاه نفسه و أهد افه، وقيمه و الآخرين من حوله. ويعرفه (عبد الرحمن أبو ندى، V. . r، 9 1) بأنه اتجــاه الفـرد نحسـو

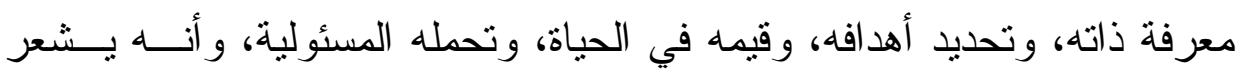

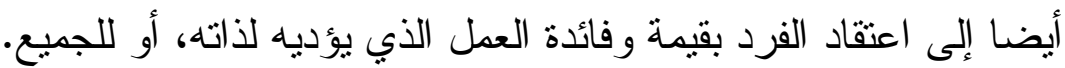
من خلال التعريفات السابقة تبين أن الالتز ام هو تبني الفرد لقيم، ومبادئ،

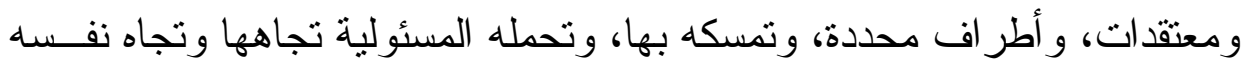
ومجتمعه، و هذا يعكس مستوى الصلابة النفسية للفرد. أنواع الالتزام: تتاولت كوباز (Kobaza, 1979) و آخــرون مكــون

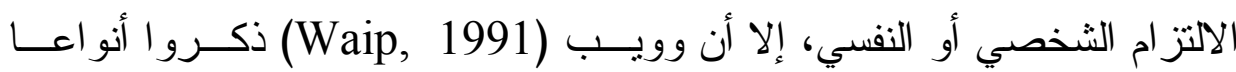
مختلفة للالثز ام، فهنالك الالتز ام تجاه الذات، وهناك الالتز ام الاجتماعي، و الالتزام

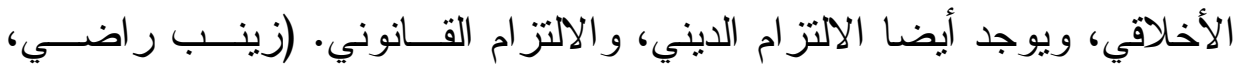
$(r \leq 6 \ldots 1$ 
وكذللك تتاولت كوباز ا (Kobaza, 1979: 103) مكون الالتز ام الشخصي

$$
\text { في و اقعها حيث رأت أنه يضم كلا من: }
$$

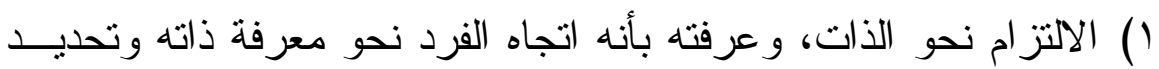

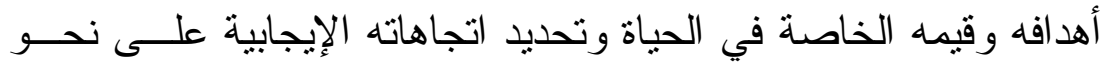

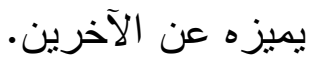

r الالتز ام تجاه العمل، وعرفته بأنه اعتقاد الفرد بقيمــة العهـلـ و أهميتـــهـ

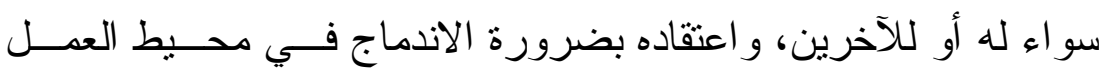
وكفاءته في إنجاز عمله، وضرورة تحمله مسئوليات العمل و الالتــزام.

(Kobaza, Maddi, puccetti, 1985, 525-532)

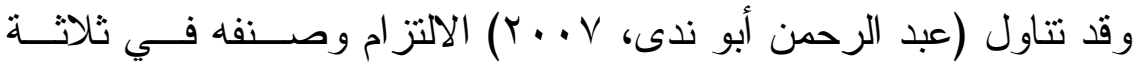

$$
\text { أنو اع وهي: }
$$

1) الالتزام الديني: حيث عرفه بأنه الثز ام المسلم بعقيــدة الإيمــان الــصحيح،

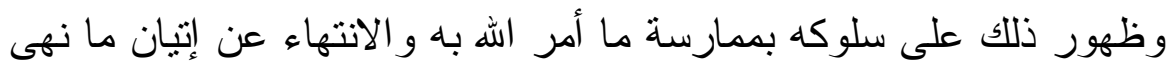

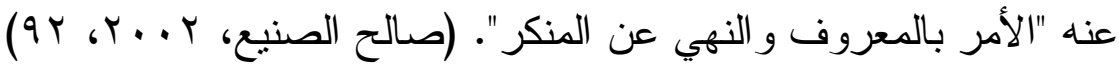
r) الالتز ام الأخلاقي: وقد عرفه جونسون (Johnson, 2004) بأنــهـ "اعتقـــاد

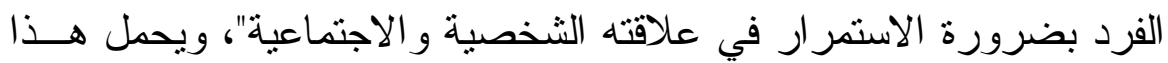
التعريف للالثز ام في مضمونه لهذا الثكل معنى الإكر اه الذاتي الذي أنثــار

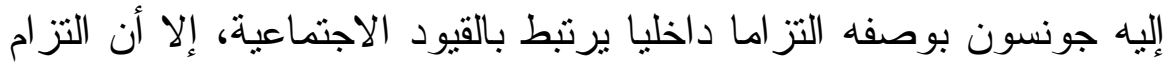

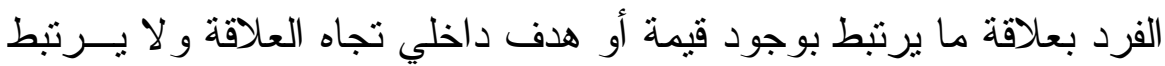
بالجو انب الأخلاقية الاجتماعية، فالفرد حين يلتزم بمجموعة من العلاقــات 
الاجتماعية الحميمة فإنه يلتزم بها من و اقع سعادته بها ورضاه عنها، وهـــا

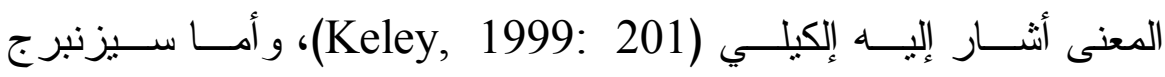
(Seznprg, 1986)

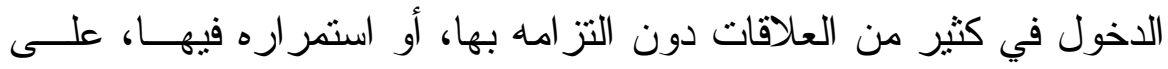

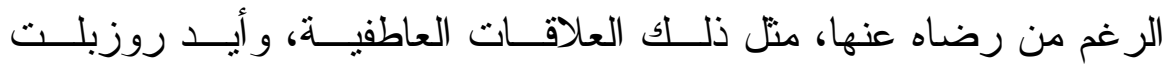

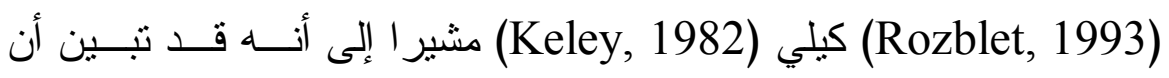
الارنباط بين الالتز ام و الرضا صفة أساسية، ومن هؤلاء فلتشر (Phtichr)

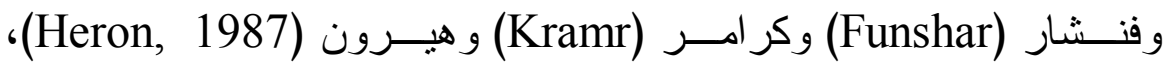

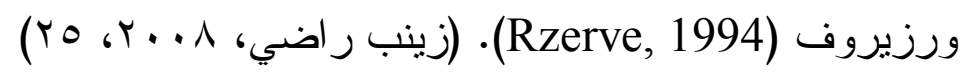
وتعكس هذه التعريفات للالتز ام الأخلاقي النظرة الغربية له، وهي نظــرة

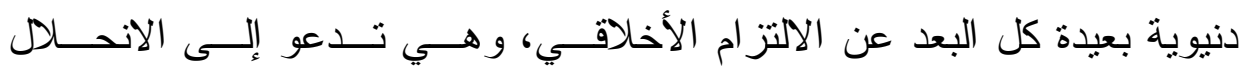

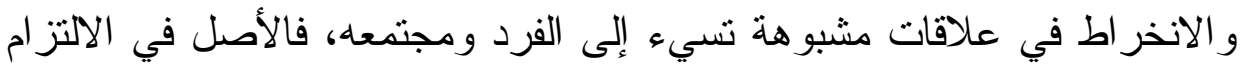

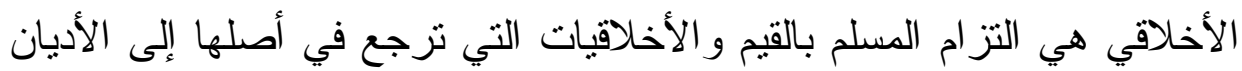

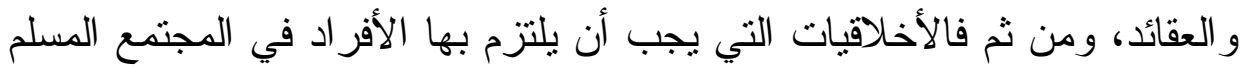

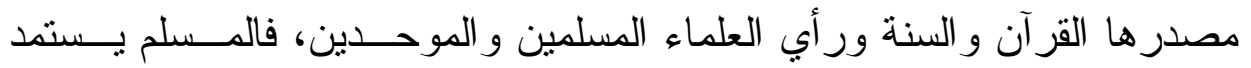
أخلاقه وقيمه من القر آن و السنة ويتعلمها ويلتزم بها فيحيا حياة طاهرة مسستقرة.

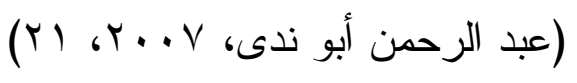

r) الالتز ام القانوني: الذي ارتبطت طبيعته ببعض المهن، وميـزت محدداتــهـ

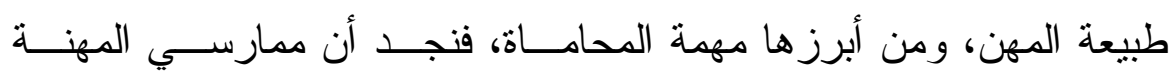

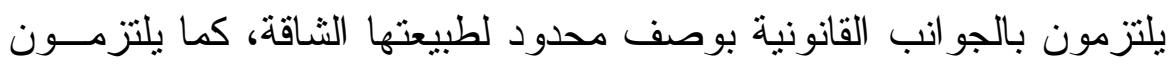
بنفس المحددات القانونية أثناء ممارسة حياتهم الثخصية. 
ويعرف علي أنه اعتقاد الفرد بضرورة الانصياع لمجموعة من القو اعــــ

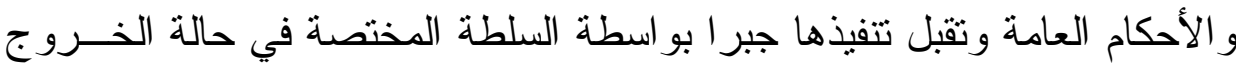

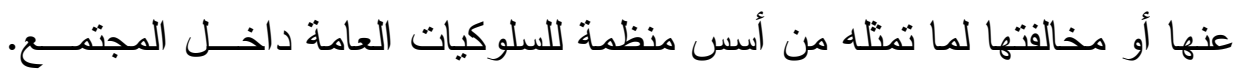
( عبد الله عادل، (199)، (199)

ويشير أبو ندى إلى أن الالتز ام قد يأتي مصدره من داخل الفرد نفسه وقد يفرض عليه جبر ا كالالتز ام القانوني، ومن ثم فلا نستطيع الحسم بكون الالتــز ام يمثل بعدا عاما أم مجموعة من الأبعاد الفرعية، ولكن كل ما يمكننا الانتهاء إليه

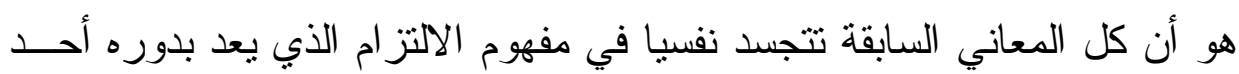

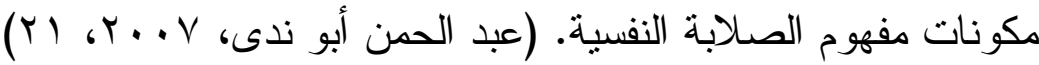

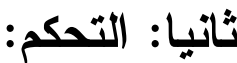

أثنارت إليه كوباز (Kobaza, 1979) بوصفه اعتقاد الفرد بأن مو اقـــ

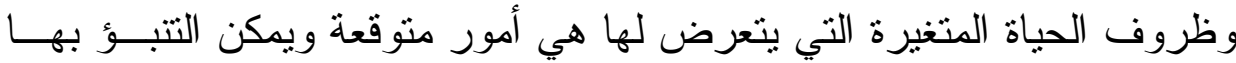

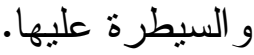

ويعرفه ويب (Weab, 1991) بأنه "اعنقاد الفرد بنوقع حدوث الأحسداث الضاغطة ورؤيتها كمو اقف و أحداث شديدة قابلة للتناول و التحكم فيها أو إمكانية

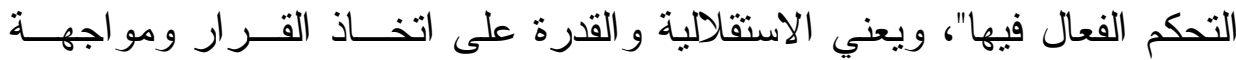

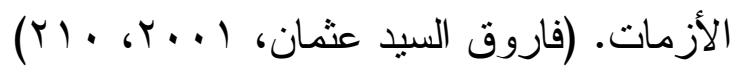
ويقول مخيمر بأن التحكم هو اعتقاد الفرد بالتحكم فيما يلقاه مـن أحسـاث

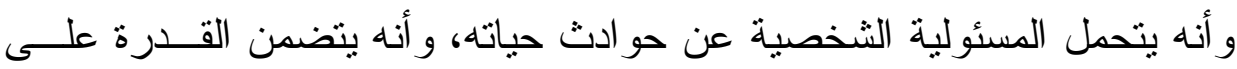

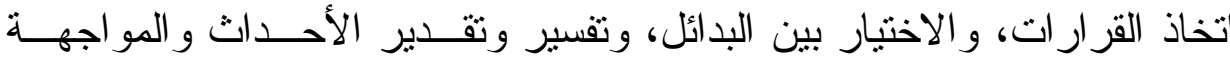


الفعالة. (عماد مخيمر، 997 (، 10 1) أما (محمد) فتشير إلـى أن الـتحكم هـــو "اعتقاد الفرد في قدرته على السيطرة، و التحكم في أحداث الحياة المتغيرة المثيرة

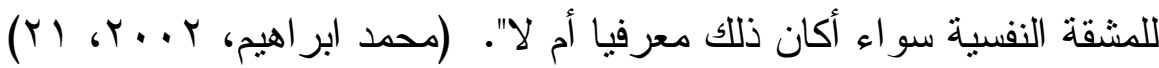
أشكال وصور التحكم:

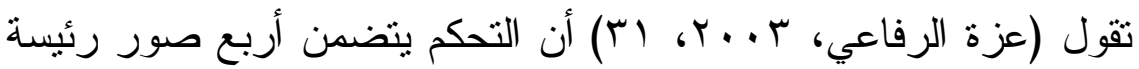

1) القدرة على اتخاذ القرارات والاختيار بين بائل متعددة: ويحسم هذا التحكم المتصل باتخاذ القرار طريقة التعامل مع الموقف سو اء بانتهائه أو تجنبـــهـ أو محاولة التعايش معه، ولذا يرتبط هذا التحكم بطبيعة الموقف نفسه وظــروف حدوثه، حيث يتضمن الاختيار من بين البدائل، فالمريض هو الذي يقرر أي الأطباء سوف يذهب إليهحم ومتى سوف يذهب، و الإجــر اءات التـي ســوف يتبعها. r) التحكم المعرفي المعلوماتي: استخدام العمليات الفكرية للتحكم فــي الحـدث يجعل التحكم المعرفي، أهم صور التحكم التي تقلل من الآثار السلبية للمشقة إذا ما تم على نحو إيجابي، فيختص هذا التحكم بالقدرة على استخدام بعــ

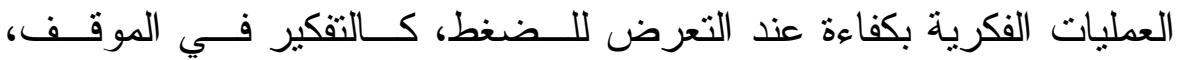
و إدر اكه بطريقة إيجابية ومتفائلة، وتقسيره بصورة منطقية وو اقعية، وبمعنى آخر أن الثخص يتحكم بالحدث الضاغط باستخدامه بعض الاسـتز اتيجيات العقلية منل تزكيز الانتباه على موضوع الضغط، أو عمـلـل خطــــة للتخلــبـ عليه، أي هو قدرة الفرد على استخدام كافة المعلومات المتاحة عن الموقــف 
لمحاولة السيطرة عليه وضبطه، ويختص التحكم بقدرة الفرد على جمع كافة المعلومات عن الحدث أو الموقف و التتبؤ بما سيؤول إلبه الحدث، أي توقـع الموقف قبل وقو عه، وذلك للتقليل من حدة الحدث، و التخفيــف مــن القلــق المصاحب للتعرض لله، وتسهيل السيطرة عليه.

ب) التحكم السلوكي: وهو القدرة على المواجهة الفعالة وبذل الجهد مع دافعيــة كبيرة للإنجاز و التحدي، ويقصد به التعامل مـــع المسـكلة بــصورة فعليــة ملموسة، و التحكم في آثار الحدث الصادم بالقيام ببعض السلوكيات المخططة

$$
\text { و المنهجية لتعديل وقع الحدث الصادم. }
$$

ع) التحكم الترجلي: ويرتبط التحكم الترجلي بخلفية الفرد السابقة عن الموقــ وطبيعته، فهذه الخلفية و المعتقدات تكون انطباعا محددا عن الموقف، وتعتبره أنه موقف ذو معنى وقابل للسيطرة عليه مما يخفف وقع الحدث الصادم. تشير كوباز ا (Kobaza, 1979) إلى أن الأشخاص الــذين يتعرضــون للضغوط ولديهم اعتقاد بقدرتهم على التحكم في أمور حياتهم هم أكثتر صــــة نفسية وجسمية من أقر انهم الذين يشعرون بالعجز في مواجهة القوة الخارجيــة، وترى أن إدر الك التحكم يظهر في القدرة على اتخاذ القرار و القدرة على التقسير و القدرة على المو اجهة الفاعلة، وفي در اسة أجر اها (أندرسون) حول العلاقة في وجهة الضبط و الثعور في بوطنة الانــضباط وســلوكيات المو اجهــة و الأداء، وله توصل خلالها أن داخلي الضبط أقل شعور ا بالضغوط و أكثر توظيفا لـسلوكيات المو اجهة المتمركزة على المشكلة، و أقل استخداما لسلوكيات المو اجهة المتمركزة على الانفعال بالمقارنة بخارجي الضبط. (عادل هريدي، V99 19، 1 (1) 


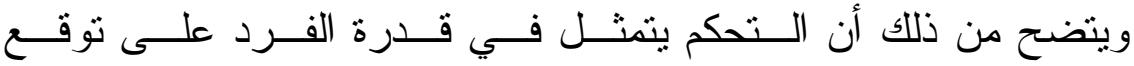

حدوث المو اقف الصعبة بناء على استقر ائه للو اقع، ووضعه الخطــــ المناســبة

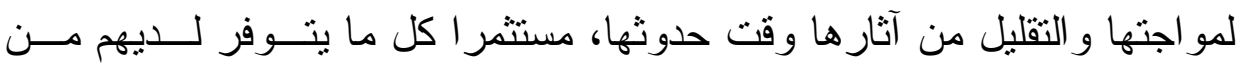

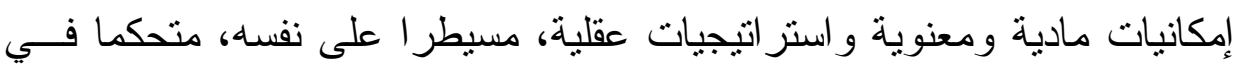

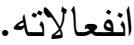
ثالثا: التحدي: - (الثا: تعرف كوباز ا (Kobaza, 1983) التحدي بأنه اعتقاد الفرد بــأن التغيــر المتجدد في أحداث الحياة وهو أمر طبيعي بل حتمي لابد منه لارتقائه، أكثر من

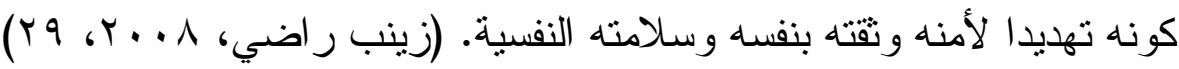
ويعرفه نوماكا و آخرون (Tomaka, et al, 1996) بأنه تلك الاستجابات المنظمة التي تتشأ ردا على المتطلبات البيئية و هذه الاستجابات تكون ذات طبيعة معرفية أو فسيولوجية أو سلوكية وقد تجتمع معا وتوصف بأنها استجابات فعالة.

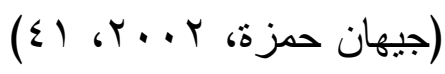
ويقول مخيمر بأن اعتقاد الثخص أن ما يطر أ من تغيــر علـى جوانــب

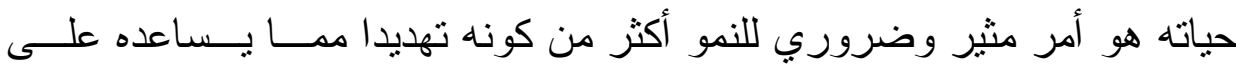

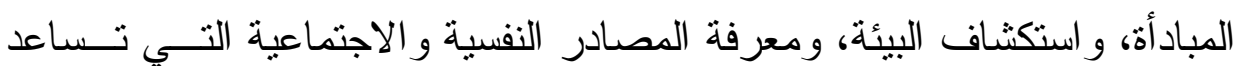

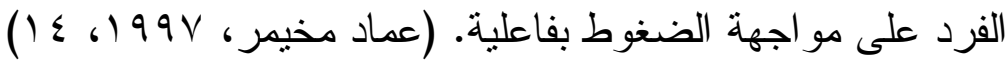
ويتضح أن التحدي يتمتل في قدرة الفرد على التكيف مع مو اقف الحيــاة

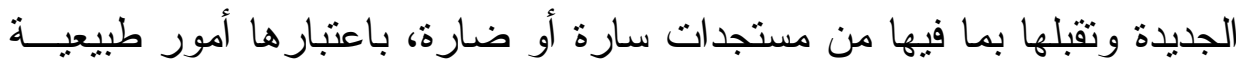
لابد من حدوثها لنموه و ارتقائه، مع قدرنه على مو اجهة المشكلات بفاعلية، وهذه

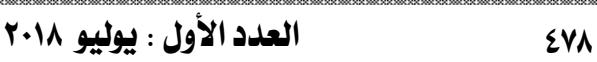


الخاصية تساعد الفرد على التكيف السريع في مواجهة أحداث الحياة الــضاغطة المؤلمة، وتخلق مشاعر التفاؤل في تقبل الخبرات الجديدة.

\section{خصال ذوي الصلابة النفسبة المُرتفعه و المُنخفضة} ( أ ) خصال ذوى الصلابة النفسية المُرتفعة :

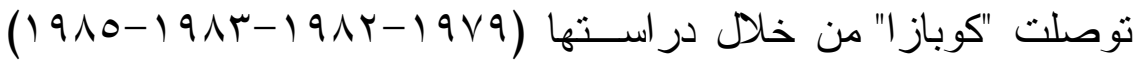

إلى أن الأفر اد المُّتعين بالصلابة النفسية يتميزون بالخصائص التالية : القدرة

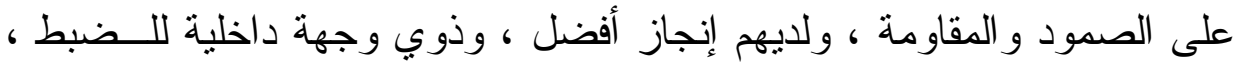

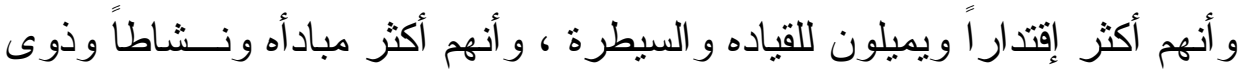
دافعية أفضل ويشعرون بصفة عامة أن لايهم قدرة على التحكم في الأحسداث .

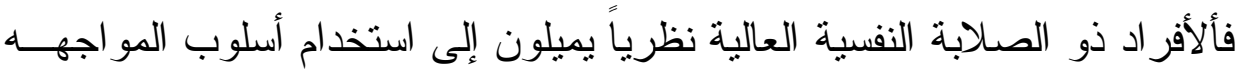

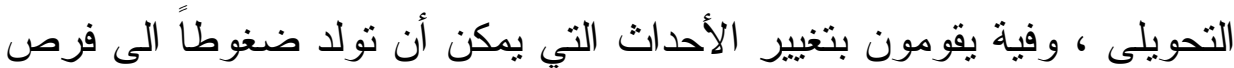

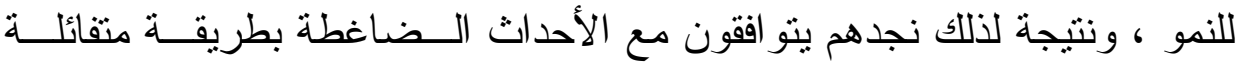

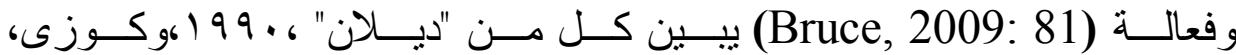
199(،وكريستونر 1997 أن أصحاب الصلابة النفسية المرتفعة لديهم أعراض نفسية وجسمية قللة وغير منهكين ، ولديهم تمركز كبير حول الذات، ويتمتعـون بالإنجاز الثخصى ، ولديهم قدرة على التحمل الإجتماعى ،وارتفاع الدافعية نحو لإن

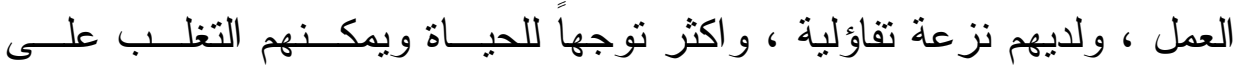

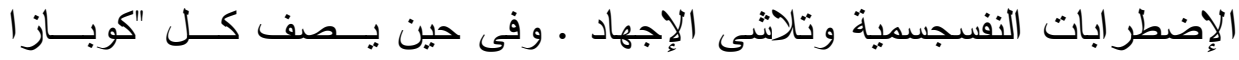
وجنتري" Kobasa\&Gentry" الأفر اد ذوى الصلابة المرتفعه بأنهم يعتمدون

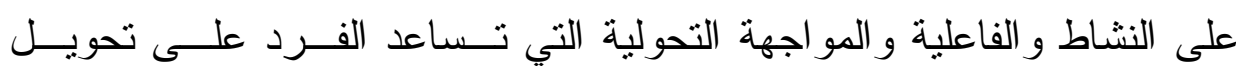


الضغوط إلى خبرة أقل بل أنهم يفضلون إستخدام استر اتيجيات المو اجهة الفعالـــة

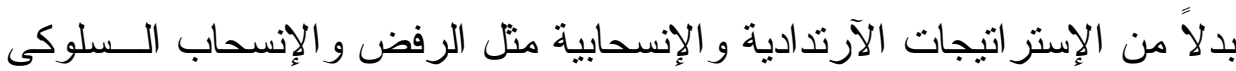
و المعرفى ، وهنالك عاملان أساسيان مؤثران في بيئة الثخصية|الــصلبة وهدــا التقييم المعرفى للموقف الضاغط وطريقة للمو اجهة التي يتبعها الفرد مع الموقف الضـاغط ـ و أكدت در اسة "باربــار ا (Barbara, 2003) " بـــأن الأفــر اد ذوي الصلابة المُرتفعه لديهم رؤية مختلفه لأنفسهم ن وللعالم من حولهح ولديهح القدرة على ممارسة تأثنيره على بيئتهم المحيطة بهم بل لديهم شعور بالقدرة على تحويل الموقف الغير مُناسب إلى وقف مفيد ونافع ، وكما أنهم يتمتعون بالإلتز ام تجـــاه الأنشطة المختلفه التي يقومون بها وتجاه عملهم ومتطلباتة ن ولـديهم إحسـاس عالى بهدفهم بالحياة بل أنهم يقيمون كل حدث يمــرون بـــه بطريقــة ســارة ن

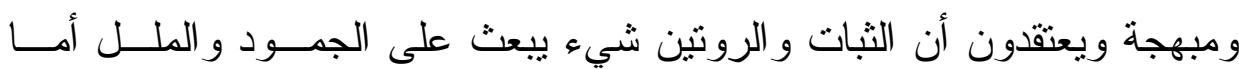
التعبير فهو طبيعة الحياة وشيء يحقق لهم الإستثارة و التشويق أكثر مــن المـــلـ و الخوف . (Barbara etal., 2003:237-238)

أثنار "باتون Bartone"(2008) إلى أن النمط ذو الثخــصية المرتفعــه

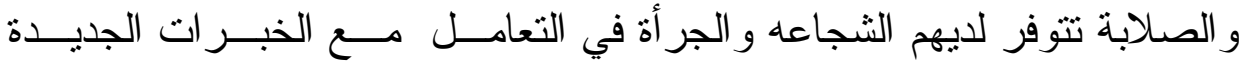
بالإضافة إلى الأشياء المخيبة للأمل ، و الميل إلى تحقيق الكفاءة بدرجة عاليـــة ، و الثخص ذو الصلابة المرتفعه يكون لدية مناعة قوية ضد الضغوط ، ويكــون ذو مقاومة شديدة في الإستجابة إلى مدى كبيــر مــن الظـــروف الــضـاغطة ،

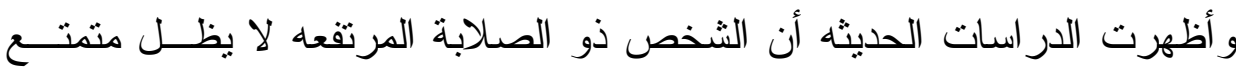

(Bartone,p.T,2008:10) بالصحة ، بل يعمل بأفضل أداء تحت الضغوط 


\section{(ب) خصال ذوي الصلابة النفسية المُنففضة :}

فقـــ وجــ "Leek, G. \& Williams, D أن الأفــر اد ذو الـــلابة

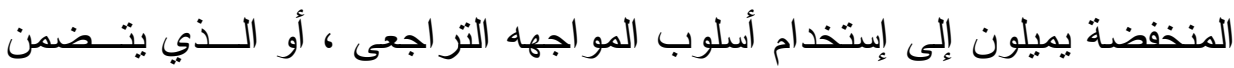

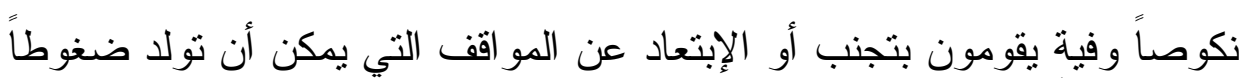

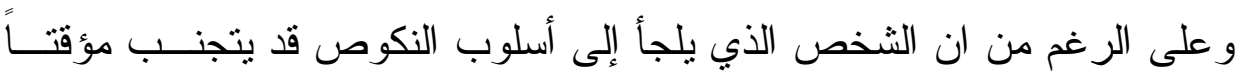

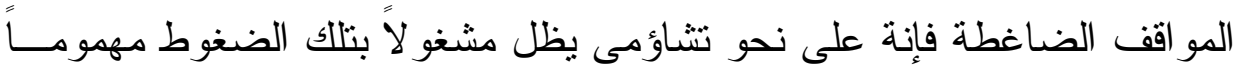
(Williams,etal.,2009: 95). بها

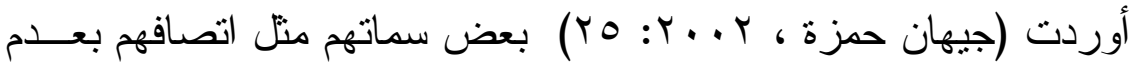

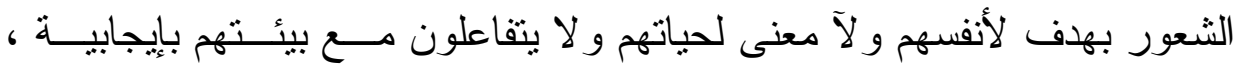

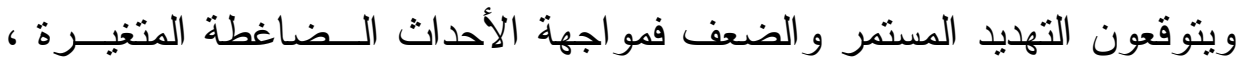

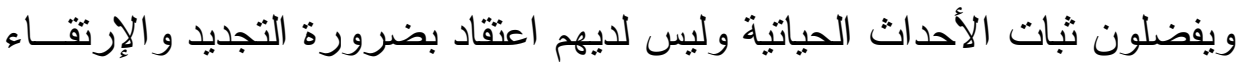

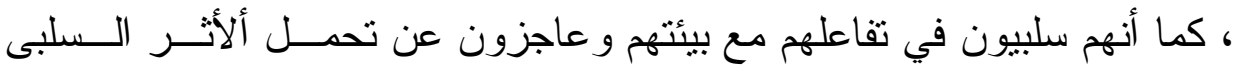

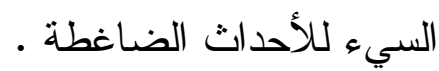

بينما وصف ( Nancy .S ) " الأفر اد ذوى الصلابة النفسية المنذفـضة

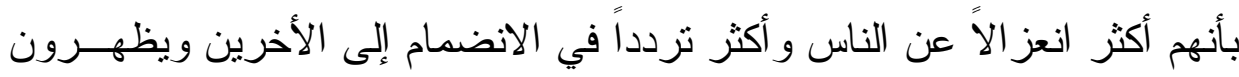
الثعور بالحيرة و القلق ويشتركون بنسبة قليلة في الأنثطة اليومية أثناء أوقـات التهات فر اغهما ويثعرون بأن الأنشطة الني يمارسونها أقل هدفاً ومعنى بالنسبة لحياتهم التهاء

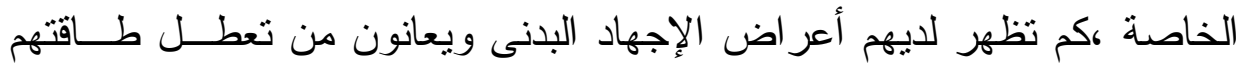

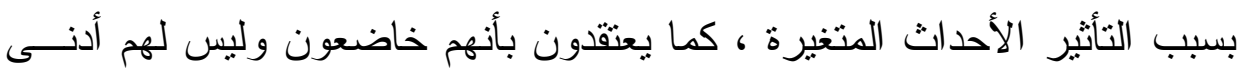

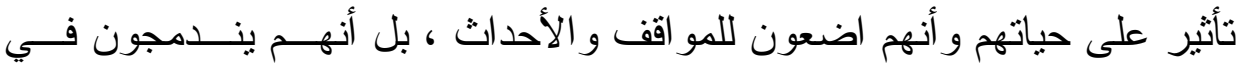


المو اقف الحياتية بنوع من السلبية و التثاؤمية ، و لآ يتمتعون بالتفكير الإبـــاعى لأنهم يحبون النمطية و الثبات و لآيفضلون البحــث عـن المــصادر أو البـــائل الإضافية المتاحة أمامهم ، بل أنهم لآيشعرون بالحماسة و الطموح في الدـستقبل

ويعانون من الغموض و الخمول • ( Nancy .S ,2008: 147 )

يتضح مما سبق أن الفرد من المدكن أن يكتسب خصال الصلابة النفسية

المرتفعه منذ نشأتة في مناخ أسرى سوي قادر على تدعيم بعـض الخــصائص

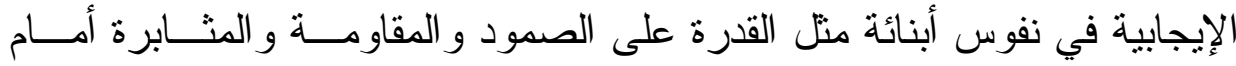

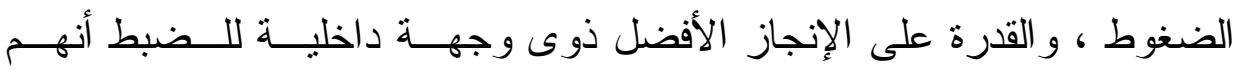

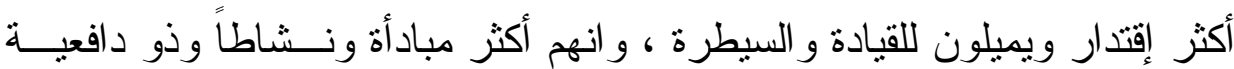

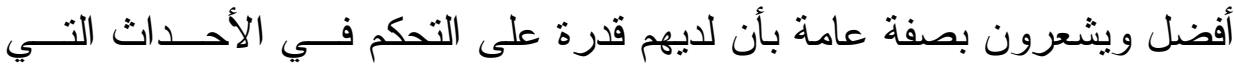

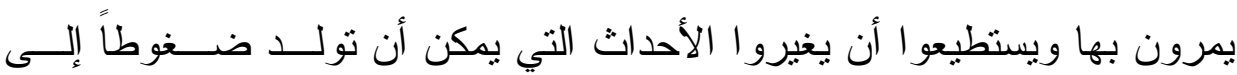
فرص للنمو.

وبذلك يمكنهم التغلب على الاضطر ابات النفسية التــي يمكـن تــو اجهمه ويكون نتيجة هذا تتشئة هذه الافر اد في اسرة متو افقة في علاقتها وقادرة علىى

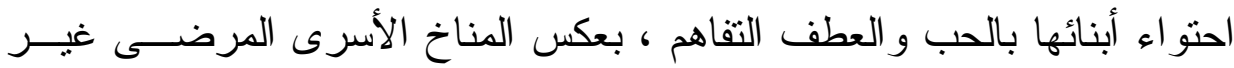

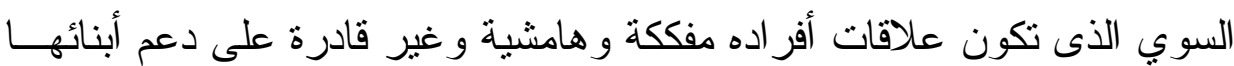
إلآ بالخصائص المريضة التي تتأثز شخصيتهم بها وتؤثز عليهم طوال حبـاتهم ويكونو ا أفر اد يتجنبون المو اقف التي تولد لهم الضغوط و لا يستطيعون المو اجهه

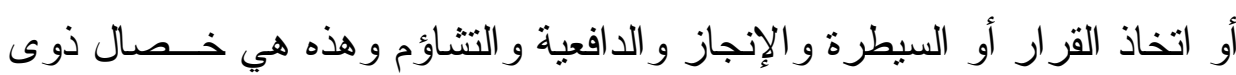

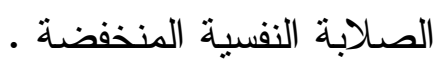




\section{الأسرة وتكوين سمة الصلابة النفسية :}

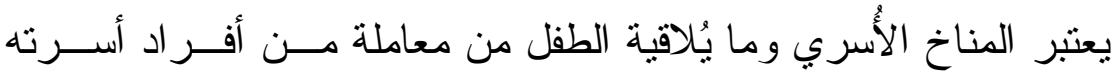

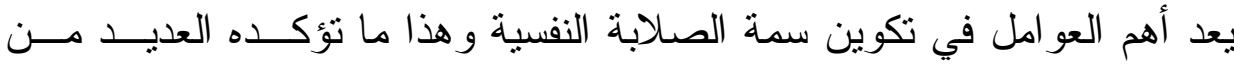

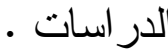

ونجد أن معظم الباحثين قد أعطو أهمية كبيرة للعوامل الخارجيــة فـي تكوين سمة الصلابة النفسية وغيرها ، بداية من الأسرة حتى الأقران ، فتحــدث (Harter)

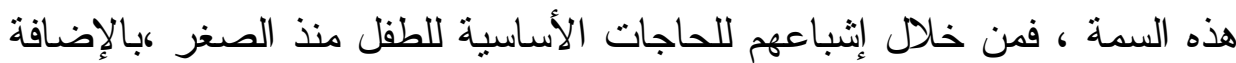
إلى إثباعهم للحاجات الثانوية كالحاجة إلى الحُب و الحنان و الـشُعور بالــدفء ،

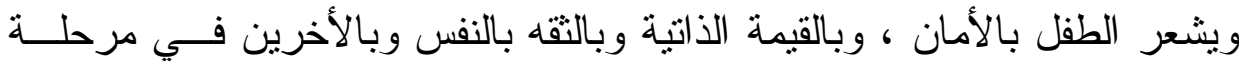

(Harter,1983:96) العمرية التالية

و أيد "لآزاروس Lazarus" أر آء إريكسون و أضاف إليها ، مُشيراً إلـى أن إحتر ام الو الدين لأر اء الطفل منذ الصغر ، ووضـــع مسستوي مناسـب مــن

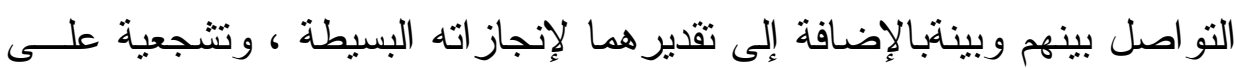
الإعتماد على نفسة عند أداء مُتطلباتة الثخصية ، يشعر الطفل بالأمان ، بالقيمة

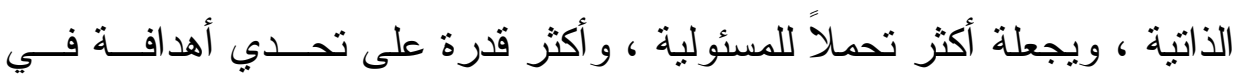

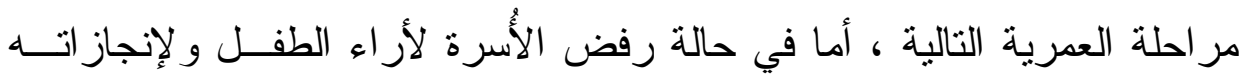
ورفض الو الدين أر آئهم فإن ذلك يشعر الطفل بالخوف ويجعله يتوقـع حسدوث

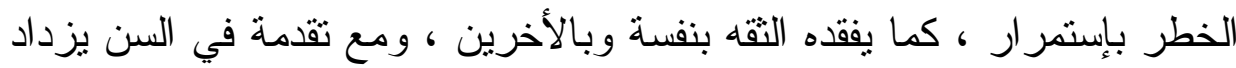

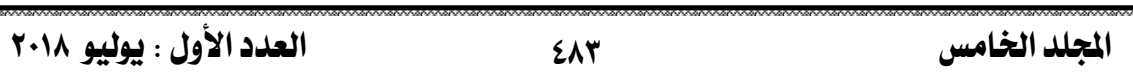


لدية الثعور بالتهديد من التعرض للمو اقف الجديده فما تقدمة في مر احلة العمرية (Lazarus, 1984: 109) النالية

أما"بولبى Bowlby فقد أكد وجود أرتباط جوهرى بين العلاقة الحميمة و الأمنه و المستمرة التي تقدمها الأسرة للطفل ، وظهــور الثخــصية الملتزمـــة

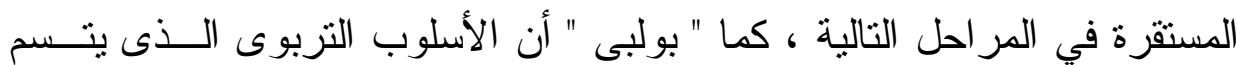

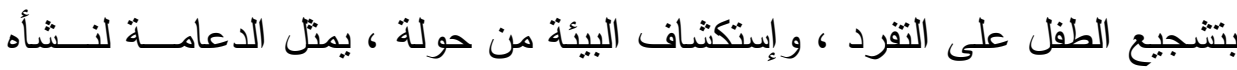
القدرة على الإلتز ام و التحكم و لإنماء الكفاءه الذاتية للطفل عند مقابلة الصعاب .

(Bowlby, 1980: 113)

و أيد "ماكوبى Maccoby " أر من سبقة من العلماء وفيما يخص منشاً سمة الصلابة ، وذلك من خلال دراستة التي أجر اها عام ، ـ191 بهـدف تبــين دور البيئة الأسرية في تكوين سمة الصلابة فيما بعد عند إدر الك المشقة و التعايش معها ،وقد أثنارت نتائج هذه الدر اسة إلى أن العلاقات الأسرية التي تتسم بالدفء و القبول و الإهتمام بالطفل و الثقه فية و الإحتر ام و التقدير له تتمى لدية الإعتقاد بأن خبر ات النجاح و الفثل ترجع لعملة ومجهوده ومدى مثابرته وتحديــة للأحسـداث

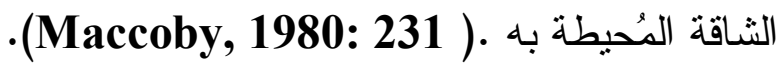
ويُشتير روتر Rutter إلى أن العلاقة الأمنة التي يسودها الدفء والحـب بين الطفل وو الديه عامل واق للفرد يؤدى إلى شعور بالكفاءة و الثقه و القدرة على المو اجهة و التحدي ، بينما عدم وجود علاقة حميمة يمكن الوثوق فيهــا تجعـل الفرد بعدم الكفاءة ، و عدم الثقه ، و العجز في المو اجهة ،بل إن عدم وجود علاقة 
حميمة قد يمنل مفتاحاً لفهم الإكتئاب بل و التتبؤ بإضطربات الثخصية الأخــرى ( IV9 : عماد مخيمر 1997) وتبين در اسة عماد مخيمر (799 19) أن العلاقة التي تتسم بالــدفء بـين

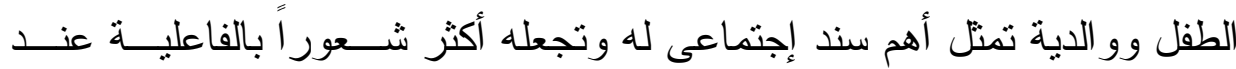
مو اجهة الضغوط ، فإدر الك الأبناء للاف أبي أعتقادهم أنهم محبوبيين إذا أقتــرن

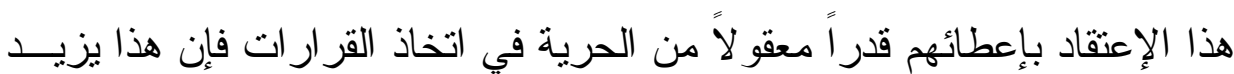

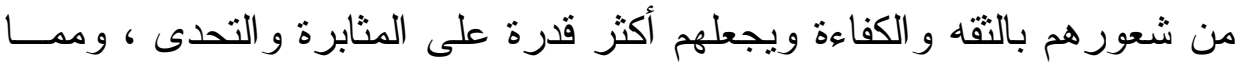
يجعهم يعتقدون أن الضغوط التي نو اجههم ليست تهديداً لهم بقدر ما هي اختيار

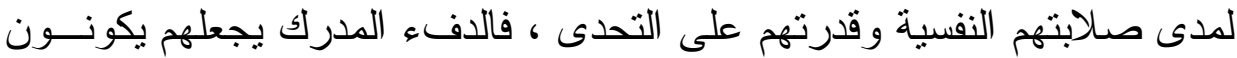
صيغة إيجابية عن الذات و العالم و المستقبل ، وهذه الصيغه تتــضمن إدر اكهـم لكفايتهم وفاعليتهم ،مما يجعلهـم يعتقــدون أن بإمكــانهم مو اجهــة المــشكلات

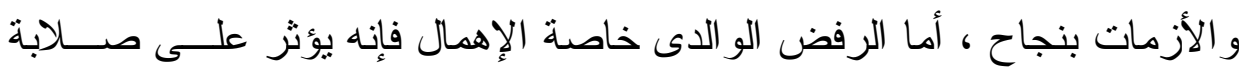

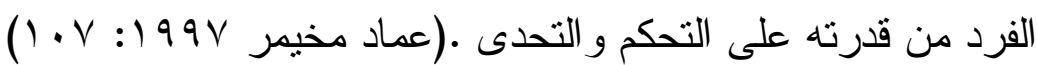




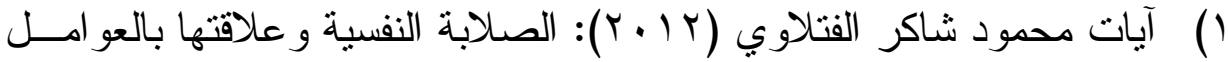
الخمسة الكبرى للثخصية لاى طلبة الجامعـة، رســالة ماجـستير ، كليــة التزبية، جامعة كربلاء، العر اق.

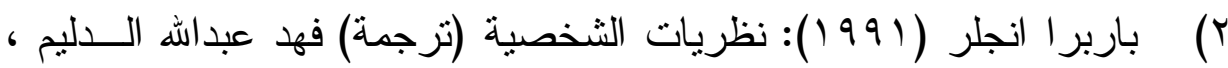
الطائف ، النادي الأدبي.

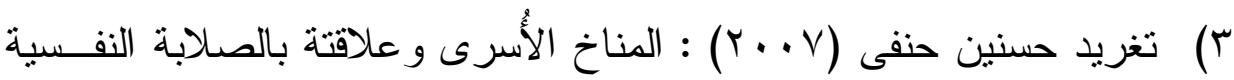
لاى المر اهقين من الجنسين رسالة ماجستير غير منشورة ، جامعة القاهرة،

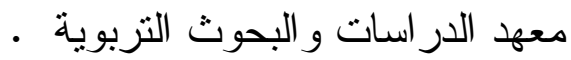

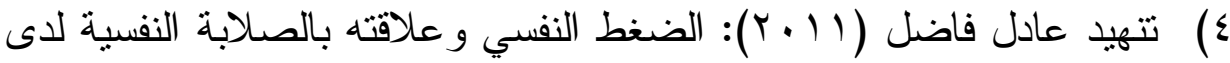

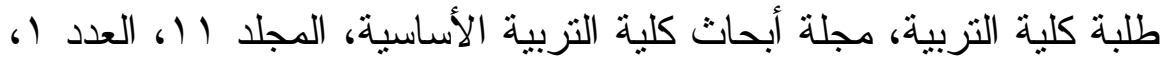

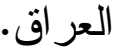

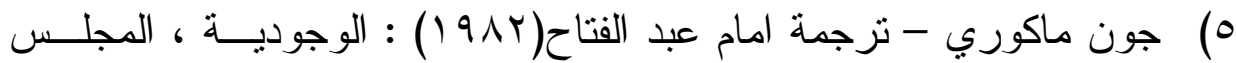
الوطني للنقافة ، الكويت . 7) جير اكور - ترجمة طالب خفاجة(910 1) : "الارشاد و العلاج النفسي بـين النظرية و التطبيق " الطبعة الأولى ،مكتبة الفيصلين ،القاهرة .

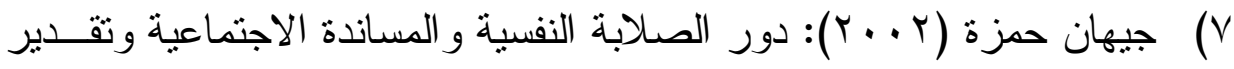
الذات في إدر الك المشقة و التعايش معها لدى الر انثدين من الجنـسين فــي سياق العمل، رسالة ماجستير غير منشورة، جامعة القاهرة، كليــة الآداب، قسم علم النفس. 


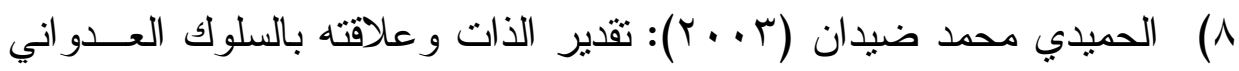
لدى طلبة المرحلة المتوسطة بمدينة الريــاض، رســالة ماجـستير ، كليــة الدر اسات العليا، أكاديمية نايف العربية للعلوم الأمنية، السعودية.

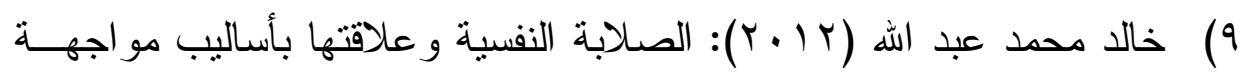

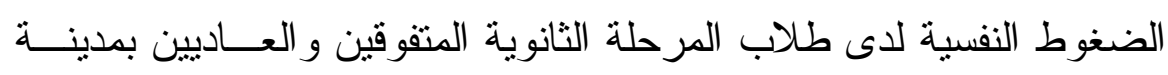
مكة المكرمة، رسالة ماجستير ، كلية التربية، جامعة أم القرى، السعودية.

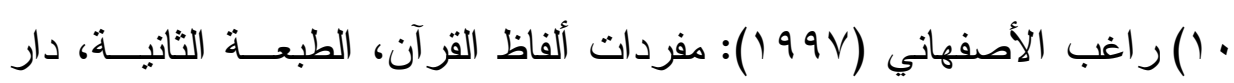
القلم، دمشق.

(1) رشاد موسى (997 (1)): سيكولوجية التدين، مجلة التقويم و القيــاس النفـسي

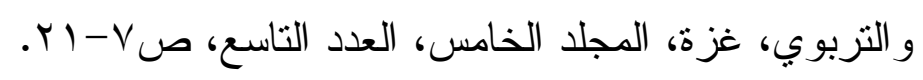

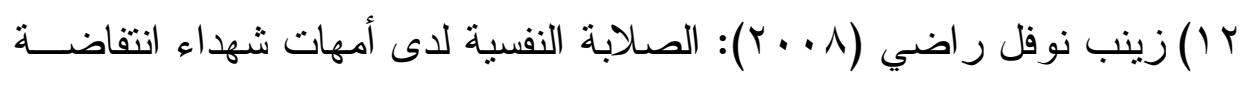

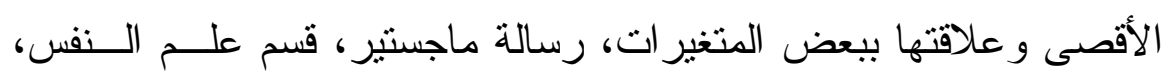
كلية التزبية، الجامعة الإسلامية، غزة.

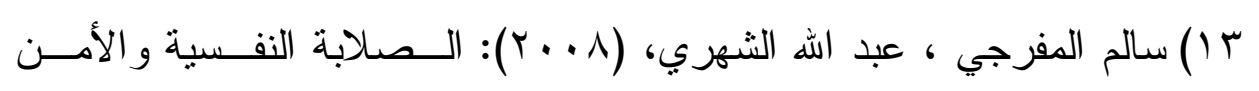
النفسي لاى عينة من طلاب وطالبات جامعة أم القرى بمكة المكرمة، مجلة علم النفس المعاصر و العلوم الإنسانية، عدد 9 1، المنيا، جامعة المنيا. ع ( ) سيد أحمد البهاص (Y . . r): الناهك النفسي و علاقته بالصلابة النفسية لدى معلمي ومعلمات التزبية الخاصة، مجلة كلية التربية، جامعة طنطا، العــدد

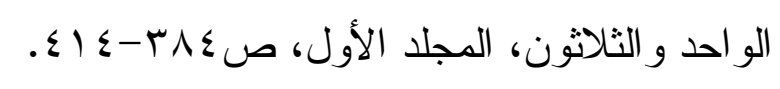




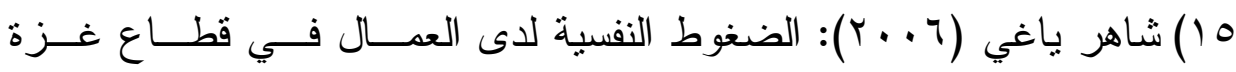
و علاقتها بالصلابة النفسية، رسالة ماجستير غير منشورة، قسم علم النفس، كلية التربية، الجامعة الإسلامية، غزة.

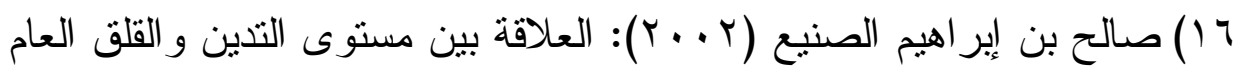

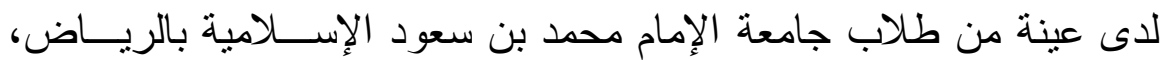

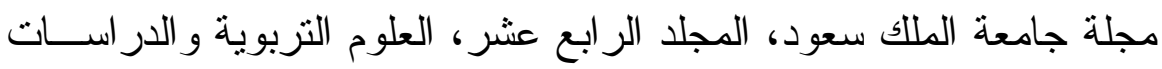

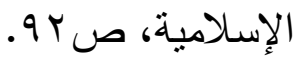

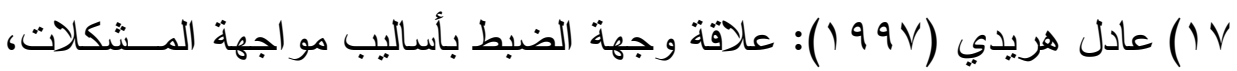

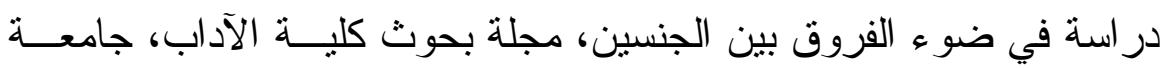

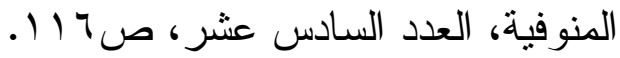

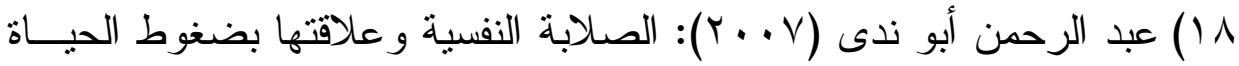

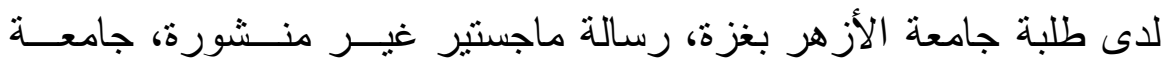
الأزهر بغزة، كلية التزبية، قسم علم النفس. 9 1) عبد الله عادل (1991): اختبار تقدير الذات للمر اهقين و الر اثندين، القاهرة،

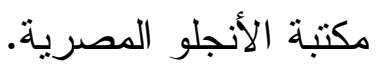

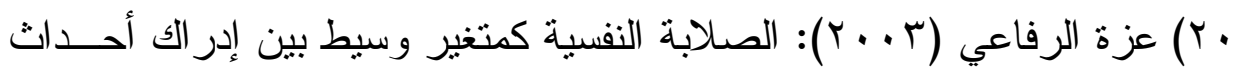

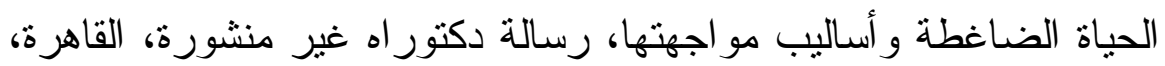

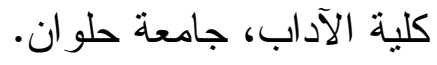

